\title{
Spirifer disjunctus (Sowerby, J. de C. in Sedgwick \& Murchison, 1840) and S. verneuili Murchison, 1840 (Brachiopoda, Spiriferida): 175 years of confusion
}

\author{
Paul SARTENAER
}

P. Sartenaer passed away in July 2015, shortly after this paper was finalised. Since his retirement as Honorary Head of the Department of Palaeontology he continued working at the Royal Belgian Institute of Natural Sciences (RBINS), rue Vautier 29, B-1000 Brussels, Belgium.

ABSTRACT. 'Spirifera disjuncta' Soverby, J. de C in Sedgwick \& Murchison, 1840 and 'Spirifer Verneuili' Murchison, 1840 were declared synonyms in 1840. 'Spirifera disjuncta' is based on a type series consisting of moulds of three specimens from the Upper Devonian of England: one from the Strunian of Barnstaple, North Devon, and two from the upper Famennian of Petherwin, North Cornwall. The type series of 'Spirifer Verneuili' is composed of three specimens from the Frasnian of Boulonnais, France. Lectotypes are designated herein. The acceptance of the synonymy of the two species, which still prevails, is considered unjustified.

KEYWORDS: Spiriferids, England, Boulonnais (France), Upper Devonian.

RÉSUMÉ. Spirifer disjunctus (Sowerby, J. de C. in Sedgwick \& Murchison, 1840) et S. verneuili Murchison, 1840 (Brachiopoda, Spiriferida): 175 années de confusion. 'Spirifera disjuncta' Sowerby, J. de C. in Sedgwick \& Murchison, 1840 et 'Spirifer Verneuili' Murchison, 1840 ont été déclarés synonymes en 1840. 'Spirifera disjuncta' est basé sur une série type comprenant les moules de trois spécimens du Dévonien supérieur d'Angleterre : un spécimen provient du Strunien de Barnstaple dans le nord du Devon, les deux autres du Famennien supérieur de Petherwin dans le nord des Cornouailles. La série type de 'Spirifer Verneuili' comprend trois spécimens du Frasnien du Boulonnais en France. Des lectotypes sont désignés dans ce travail. La synonymie acceptée des deux espèces prévaut encore à l'heure actuelle; elle est considérée injustifiée.

MOTS-CLÉS: Spiriférides, Angleterre, Boulonnais (France), Dévonien supérieur.

\section{Introduction}

Judging by the number of descriptions (in tens), figures (in tens), references (in hundreds), and citations (in thousands), it seems evident that 'Spirifera disjuncta' Sowerby, J. de C. in Sedgwick \& Murchison, 1840 is a well-known and universally recognized species ${ }^{1}$.

The reality is that 175 years elapsed since the species was introduced, and, still, no single palaeontologist has attempted to come up with a proper definition of the species in its type area lato sensu (North Cornwall and North Devon). The three specimens of the type series, housed in the Sedgwick Museum of Earth Sciences, University of Cambridge since the species was proposed, have never been mentioned in the literature. Moreover, Sokiran (2013, p. 24) has been notified by Michael G. Bassett and Leonid E. Popov that the type series of this species was lost.

In the year 1840, when the Devonian System came to light in SW England, some new spiriferid species were established in Devon and Cornwall. Based on poorly preserved material and unsatisfactory descriptions and illustrations, these species led to multiple and mostly vain discussions in the literature. One of them, 'Spirifera disjuncta', enjoyed worldwide distribution, and extended stratigraphic range in spite or probably on account of its definition, rendered impossible without a type being designated among its type series.

At the same time, the Devonian System was circumscribed in continental Europe, and its upper part was undergoing active investigations by British and French geologists in Boulonnais, France. New spiriferid species were also established, but, contrary to the situation in England, their description by Murchison rested on well-preserved material. The same year, one of them, 'Spirifer Verneuili', was declared identical to 'Spirifera disjuncta'. Equivalence of these two species, which won over the support of all renowned palaeontologists of that time and of the years after, is still surviving, although 'Spirifer Verneuili' later became the type species of the genus Cyrtospirifer Nalivkin in Frederiks, 1924. Fallacy of this equivalence is here put in evidence.
Specimens studied are housed in the Sedgwick Museum of Earth Sciences, University of Cambridge (with specimen number prefixed: CAMSM) and in the Natural History Museum, London (formerly British Museum of Natural History) (with specimen number prefixed: BMNH or NHMUK PAL BD).

\section{The identity card of disjunctus}

\subsection{The three specimens of the type series}

The original description by Sowerby, J. de C. in Sedgwick \& Murchison (1840, pl. LIII, fig. 8, pl. LIV, figs 12, 13), illustrated by the figures of the three specimens constituting the type series is as follows:

'Plate LIII, Fig. 8. 'Spirifera disjuncta'. This, which is a cast of the inside of the upper valve, appears to belong to the species thus named, and is a good illustration of the internal structure of the genus, exhibiting the beak, the muscular impressions, the central striated foramen (= cardinal process), and also the hinge area (= ventral hinge area) with its striated structure" (italics by the present author).

"Plate LIV, Figs. 12, 13. 'Spirifera disjuncta'. Semicircular, with an emarginate front, very convex, radiated; upper valve with about 12 ribs, much raised in the front, forming a rounded elevation; ribs rounded, numerous, about 25 on each side the middle; beaks remote; hinge-area broad, curved, its edges nearly parallel. The specimens of this shell are so generally distorted, that its true form is seldom to be clearly made out; and this, added to the difficulty, which already exists of determining between the most perfect specimens of different species, renders it very difficult to ascertain to what species they belong. Perhaps even the ' $S$. gigantea' from Tintagel (North Cornwall, $14 \mathrm{~km}$ to the northwest of Petherwin) (pl. LV, figs 1 to 4) may be distorted individuals of this species" (italics by the present author). (Remark: it is evident that the first half of the description can only apply to the specimen of fig. 13).

\footnotetext{
It has to be noted that species names which have been put between single quotation marks in the following, refer to the names used in the
} original description of the species. 
The three specimens of the type series of 'Spirifera disjuncta' figured by Sowerby housed in the Sedgwick Museum of Earth Sciences, University of Cambridge are: CAMSM H.841 from Barnstaple, North Devon, and two specimens, CAMSM H.4008 and CAMSM H.4009, from Petherwin, North Cornwall. The specimen CAMSM H.841 (P1. 1, Figs A-B) is the mould of an almost complete and large dorsal valve plus the interarea of the ventral valve (Fig. $\mathrm{A}=$ pl. LIII, fig. 8 of Sowerby; Fig. B represents internal cast of the specimen). The specimen is larger than hitherto estimated, since part of the margin of its anterior part has been omitted in the woodcut figured by Sowerby. Specimen CAMSM H.4008 is the mould of a very large, flattened, distorted, and poorly preserved ventral valve (Pl. 2, Fig. $\mathrm{A}=$ pl. LIV, fig. 12 of Sowerby), and specimen CAMSM H.4009 (Pl. 2, Figs B-F; Fig. B = pl. LIV, fig. 13 of Sowerby) is a large complete specimen (mould), less large than specimen CAMSM H.841.

\subsubsection{Designation of a lectotype}

Although the three specimens of the type series are very different from each other, no palaeontologist dealing with spiriferids considered it necessary to designate a lectotype.

The choice of a lectotype has to be between the specimen from Barnstaple and two specimens from Petherwin. Specimen CAMSM H.841 (P1. 1, Figs A-B) is here formally designated as the lectotype of Spirifer disjunctus. As a fair representative of the abundant similar and slightly distorted moulds from Barnstaple, it allows, in conjunction with them, to observe and define the internal characters of the species. External characters, such as outline, costae, development of fold, dorsal muscle field, and ventral interarea are also visible on the specimen.

\subsubsection{Paralectotypes}

Specimen CAMSM H.4008 (Pl. 2, Fig. A), here called paralectotype A, shows the ventral muscle field delimited by the dental plates. Large size specimens assigned to the species, as disjuncta or verneuili, are not uncommon in the material from Petherwin in the large existing collections.

Although it seems to be the obvious choice, the complete and well-preserved specimen CAMSM H.4009 (Pl. 2, Figs B-F), here called paralectotype $\mathrm{B}$, is not designated the lectotype of $S$. disjunctus for the two following reasons. First, the preserved shell and costae of this complete and not deformed specimen makes it unique. Collections from around Petherwin show no specimen that matches it, but contain some slightly deformed complete or nearly complete specimens, which are similar to paralectotype B in size, outline, and profile, but are worn out, and looking like rolling pebbles. Secondly, the name disjuncta given by Sowerby indicates that he considered the large number of separated valves found around Barnstaple and Petherwin better suited for defining the species.

\subsection{Material}

Collections of the Natural History Museum, London and of the Sedgwick Museum of Earth Sciences, University of Cambridge.

The material from Barnstaple (labelled Barnstaple) is almost exclusively composed of moulds of small, large, and even very large, isolated (disjuncted) valves (more ventral than dorsal ones), almost not or not at all distorted (small specimens are never distorted), crushed, often fragmentary, sometimes embedded in matrix. Complete specimens are exceptional. In three specimens, including the lectotype, the articulation of both (incomplete) valves is visible. Plate 1, Figs D-F show specimens of various sizes: CAMSM H.1342, mould of a complete crushed specimen (Fig. D); CAMSM H.868, isolated dorsal valve (Fig. E); CAMSM H.859, large specimen similar in size to the lectotype (Fig. F).

Specimens from Petherwin show the same range of sizes as the ones from Barnstaple, but very large specimens are more common. All of them are deformed, distorted and crushed, often fragmentary, and sometimes embedded in matrix. Isolated (disjuncted) valves (more ventral than dorsal ones) are the rule, some of them preserved as moulds. The articulation of both (incomplete) valves is visible on three moulds. One of the characteristics of the material of Petherwin is the occurrence of large and very large complete or almost complete specimens that are only slightly deformed and look like rolling pebbles, both valves being strongly convex, worn out and glazed. Some of them (specimen BMNH 32965b, Pl. 2, Fig. G) have the outline, profile and size of the paralectotype B.

Most small specimens from Barnstaple and Petherwin have the greenish colour of the rock in which they are embedded, others are brownish (most), grey, reddish, and, exceptionally, rust-coloured. Surfaces of specimens from Petherwin are locally asphalt-black.

\subsection{Stratigraphic range}

When $S$. disjunctus was proposed as a new species, the "calcareous slates" from South Petherwin and Barnstaple were considered by Sedgwick \& Murchison (1840, pp. 668, 694-695) as having a "symmetrical position", forming "an upper group of the great slaty series", and appearing "on the whole to form a mineral passage into the overlying system".

Recent knowledge indicates that these beds, in which disjunctus is declared to be found, are of different age.

The series of slates with thin limestones yielding the spiriferids from South Petherwin form the late Famennian Upper Petherwin Beds (upper Platyclymenia and Clymenia "Stages").

The graded siltstones and shales with calcareous bands and sandstones around Barnstaple that are rich in spiriferids correspond to the lower Pilton Formation, i.e. to the Wocklumeria Zone (probably the upper Wocklumeria Zone) or to the upper Siphonodella praesulcata Zone in terms of conodont succession. These beds are commonly correlated with part or whole of the Stourscombe Beds overlying the Upper Petherwin Beds of North Cornwall, and, more generally, to the Strunian (Étroeungt Beds).

\section{The identity card of verneuili}

\subsection{The type series}

Murchison (1840b, p. 252, pl. II, figs 3a-e) described as 'Spirifer Verneuili' the species from Ferques (Boulonnais, France), Golzinne and Rhisnes (Namur Basin, Belgium), and Chimay (Dinant Basin, Belgium). From "une série de passages depuis les individus les plus transverses jusqu'à d'autres beaucoup plus renflés et très volumineux", and "nombreuses variétés" at his disposal he figured three specimens from Ferques: a large one (figs 3a, b, d), a small one (fig. 3c), and a very small one (fig. 3e) (Fig. 1). These figured specimens that make up the type series have not been located since, and are considered lost. (Remark: figures of these three specimens are idealized. In particular figs $3 \mathrm{a}, \mathrm{b}, \mathrm{d}$ are considered as representing a single specimen in spite of some evident contradictions between them: fig. $3 \mathrm{~d}$ does not show the broken cardinal extremity present on figs $3 \mathrm{a}, \mathrm{b}$; no orientation of fig. $3 \mathrm{~d}$ allows the representation of the ventral interarea as it is on fig $3 \mathrm{a}$; etc.)

Brice (1988, p. 365) considered the large specimen gerontic and somewhat exceptional, and added that such individuals were rare and almost exclusively encountered in the upper part (uppermost Mesotaxis asymmetrica Zone and lowermost Ancyrognathus triangularis Zone) of the Ferques Limestone. Vandercammen (1959, fig. 89, p. 117) already considered similar specimens gerontic.

The two other specimens have been qualified as "individus jeunes des deux variétés” by Murchison (1840b, p. 252).

\subsubsection{Designation of a lectotype}

Murchison (1840b) did not select a specimen to be the type of verneuili. On the contrary, he clearly indicated that he considered the species as a whole, composed of the "variétés" and "passages" just mentioned.

Therefore, statements such as "le type décrit par Murchison" (Brice in Joseph et al., 1980, p. 36) or "On peut regretter que Murchison ait choisi de figurer, comme type de l'espèce, un spécimen gérontique" (Brice, 1988, p. 365) are not justified. 


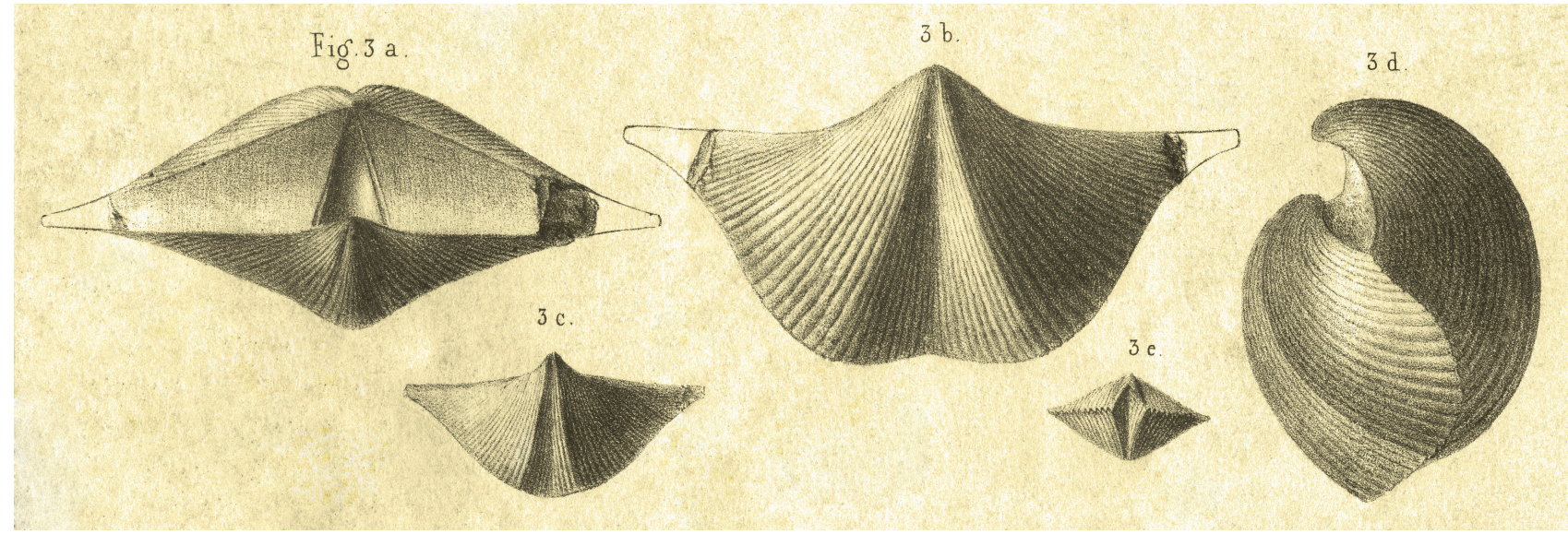

Figure 1. Original figures of Spirifer verneuili Murchison, 1840. After Murchison, 1840b (pl. II, figs 3a-e).

Grabau (1931, p. 227, fig. 19, p. 228) considered that the "individual [of Spirifer verneuili] figured by Murchison fig. $3 \mathrm{a} b$ \& d on pl. II must be considered the holotype". Such a designation is not acceptable, because the type series of verneuili includes two other specimens (figs $3 \mathrm{c}, 3 \mathrm{e}$ ) that are mentioned by Grabau in the first line of his synonymy list of S. verneuili as follows: "Figs. 3a, b \& d (3c, 3e?)".

Paeckelmann (1942, p. 79) followed suit in accepting Grabau's "holotype" as the "type" of "Spirifer (Cyrtospirifer) verneuili Murchison, nov. em., typus", and so did Brice (1988, p 365).

The "holotype" of verneuili, figured by Murchison (1840b, pl. II, figs $3 \mathrm{a}, \mathrm{b}, \mathrm{d})$ is formally designated here the lectotype of the species.

\subsubsection{Paralectotypes}

The two other specimens figured by Murchison (1840b, pl. II, figs $3 \mathrm{c}$ and $3 \mathrm{e}$ ) become paralectotypes.

\subsection{Material}

All material collected at Ferques is excellently preserved.

\subsection{Stratigraphic range}

The only stratigraphic information given by Murchison $(1840 \mathrm{~b}$, pp. 250,255$)$ on the position of verneuili in the beds cropping out at Ferques is as follows: "couches anciennes du Bas-Boulonnais" or "couches dévoniennes du BasBoulonnais" or "calcaire inférieur du Bas-Boulonnais".

It has been indicated above that Brice (1988, p. 365) considered that individuals similar to the lectotype were almost exclusively found in the upper part of the Ferques Limestone, i.e. in the upper middle Frasnian.

The present author collected specimens similar to the paralectotypes from two middle Frasnian levels in the Ferques Limestone, each of them different from the level of the lectotype: at $15 \mathrm{~m}$ below the top (very small specimens), and near the base (small specimens).

\subsection{Remarks}

The author tried to locate the type series of verneuili in writing to various institutions, including the "Musée de Boulogne", now incorporated in the "Château musée de Boulogne-surMer". The following excerpt from a paper by Cocks (1989, p. 33) encouraged him to make a last attempt: "It is worth recording that there are 11 specimens (registered B19163-6) all from the "Boulonnais" area, France (which includes the Ferques inlier), which were selected by Bouchard and were transferred from the Museum of Practical Geology to the British Museum (Natural History) with the rest of its foreign collections in 1905, these probably include at least some of the original specimens used by Murchison in 1840, although Murchison's figures appear rather generalized".
Bouchard has been a contributor to the establishment of verneuili. Murchison (1840a, p. 241; 1840b, pp. 250-251, 253) declared that "en passant par Boulogne" he examined a "riche collection de fossiles faite par Monsieur Bouchard" and expressed his gratitude in establishing 'Spirifer Bouchardi' Murchison, 1840b. Paeckelmann did not fail to mention that the wide alate form with high horizontal area ("breitflügelige Form mit hoher horizontaler Area") was sometimes, according to a personal communication by P. Pruvost, present in the collections from Ferques under the nomen manuscriptum Spirifer gailloni Bouchard.

The collection of sixteen specimens, now prefixed NHMUK PAL BD 12993-13085, 19163-19165, was kindly sent on loan to the author for examination. It contains nine specimens having the size of those originally figured by Murchison (1840b, pl. II): two large specimens (Murchison's figs 3a, b, d), five small specimens (Murchison's fig. 3c), and two very small specimens (Murchison's fig. 3e). The anterior view of the specimen BD 13002 is almost a perfect match of Murchison's fig. 3e; the ventral view of the specimen BD 13001 is similar to the one of Murchison's fig. 3c; the lateral view of the specimen BD 12996 is comparable to the one of the lectotype (Murchison's fig. 3d). The other seven specimens are of medium size and belong to Cyrtospirifer syringothyriformis (Paeckelmann, 1942).

Any definition of verneuili that does not turn around its lectotype (former "holotype", or type) is unacceptable no matter if it is declared gerontic and rare. On the other hand, the founder's concept of the species cannot be neglected. Considering "the most important Spirifer" at Ferques and at various Belgian localities in the Dinant and Namur Basins, Murchison (1840b, p. 252) included in it "de nombreuses variétés" and "une série de passages". Since then, most authors have considered verneuili an abundant species, and some of them giving formal names to some varieties of verneuili or disjunctus, which they considered synonymous with verneuili.

One of these varieties, Spirifer (Cyrtospirifer) verneuili var. syringothyriformis Paeckelmann, 1942, comes from the same type area as verneuili. On the one hand, it has commonly been included in verneuili before becoming one of its varieties; on the other hand, it has newly been considered forming a group with verneuili.

Paeckelmann (1942, pp. 123-125, pl. 4, figs 7a, b, 8a, b) had eleven specimens at his disposal when he established syringothyriformis: two "typical specimens from the FrasnesKalk" of "Boulogne-sur-mer", one of them figured (pl. 4, figs $8 \mathrm{a}, \mathrm{b}$, sketched in text-figs $60 \mathrm{a}-\mathrm{c}$ ), and nine specimens from the "Calcaire de Ferques" at Ferques, including one (pl. 4, figs 7a, b, sketched in text-figs $59 \mathrm{a}-\mathrm{c}$ ) "that can already be considered a transition to Spirifer verneuili typus, namely to the form figured by Murchison, 1840, figs 3a-d (Remark: should be $3 \mathrm{a}, \mathrm{b}, \mathrm{d})$, and to variety gosseleti Grabau, 1931”. Of the other specimens from Ferques, four are juveniles considered by Paeckelmann transitions to the "typical" verneuili. [Remark: 
Paeckelmann mentioned in the synonymy (e. p.) of the variety the two specimens from Ferques figured by Gosselet, 1894: an adult one (pl. III, fig. $16=$ 'Spirifer Verneuili, attenuati group'), and a "juvenile of second age" (pl. V, figs 43a-c $=$ ' $S$. Verneuili') of Famennian age, however in the text Paeckelmann (1942, p. 40) attributed to it a Frasnian age.] More generally Paeckelmann stated that syringothyriformis was a "form connected with transition forms to the wide alate forms of Spirifer verneuili typus and of the variety gosseleti, and, like the var. n. grabaui, maintained a pronounced mucronate growth during its existence".

Paeckelmann mentioned "only one typical" specimen from the "Frasnes-Mergel" at the Breiniger Berg near Aachen, where the species is very rare contrary to transition forms to the narrower variety gosselet $i$ that are slightly more abundant.

Syringothyriformis that is nothing more than one of the twelve varieties of Spirifer (Cyrtospirifer) verneuili described by Paeckelmann, was elevated to the species rank by Vandercammen (1959, pp. 142-146, 154, pl. 4, figs 19-26), who considered it as dimorphic and present in the whole Frasnian (F2b, e, g, i, F3) of the eastern and southern borders of the Dinant Basin, Belgium, but abundant only in the upper Frasnian (F2i). The two specimens, figured by Vandercammen, come from the highest Frasnian beds (Barvaux shales, F3) and do not belong to syringothyriformis as already indicated by Joseph et al. (1980, p. 34). It seems that Vandercammen was influenced by the catacline ventral interarea occasionally present in specimens from Barvaux, but absent in specimens from other levels of the Frasnian. Specimens from Barvaux are also the only very wide Frasnian specimens in the Dinant Basin having the outline of syringothyriformis from its type area. Furthermore, none of the Belgian Frasnian specimens assigned to syringothyriformis has the distinctive microornament of the species.

From then on syringothyriformis spread to various regions in acquiring a mid- to late Frasnian (chiefly late Frasnian) age: England (boreholes), Spain (Cantabrian Cordillera; Sierra Morena), Transcaucasia, Iran (various areas), East and West Afghanistan, British Columbia, and New South Wales.

Brice in Brice et al. (1979, p. 337) designated the "typical" specimen from the "Frasnes-Kalk" of Paeckelmann (1942, fig. 60, p. 123) as the lectotype of syringothyriformis, but considered it coming from the Beaulieu Shales at Ferques: "it was without any doubt the specimen figured by Gosselet, 1894, p. 22, pl. III, fig. 16, from that formation". This was already the opinion of Vandercammen (1959, p. 142), who put Gosselet's fig. 16 in his synonymy of Cyrtospirifer syringothyriformis.

According to Brice (in Brice et al., 1979, p. 337, table IV, p. $338 ; 1982$, p. 9 , table 1, p. 13; 1986, table 1, p. 199; 1988, table 2, p. 326, p. 328), syringothyriformis in its type area ranges from the uppermost Givetian (Cédule Limestone) to the middle Frasnian (middle part of the Pâtures Member), where it reaches its acme. In the Ferques inlier, the Beaulieu Formation is composed of the three following members, from base to top: Cambresèque, Noces, Pâtures. The presence of syringothyriformis in the lowermost Cambresèque Member (Cédule Limestone) is, in the least, questionable; according to Brice in Brice et al. (1979, p. 337) it is essentially based on a single specimen mentioned in an unpublished "Diplôme d'Études Supérieures" (Devos, 1962). Nowadays, the age of the Cédule Limestone is considered as earliest Frasnian. It is therefore pertinent to admit that syringothyriformis is not to be found in the Givetian in its type area. Furthermore, it still has to be demonstrated that the species is present in the rest of the Cambresèque Member in which it has been declared "very rare" by Brice (1988, p. 368). The range of syringothyriformis has recently been extended to the top of the Pâtures Member by Brice in Mistiaen et al. $(2012$, pp. 39, 45). Thus, the presently acceptable range of syringothyriformis in its type area is from the upper part of the Noces Member to the top of the Pâtures Member, these two members forming the lower half of the middle Frasnian (Palmatolepis punctata Zone).

Ma \& Day (2003, p. 267, fig.2, p. 270, pp. 272, 273, 280, $287,290)$ put forward the concept of an upper Givetian to upper Frasnian "syringothyriformis-verneuili group" (with a "syringothyriformis subgroup" = the group without "the spinose verneuili-type") being "the most abundant and widespread group in Frasnian deposits worldwide", species of this group having "transverse alate shells". These authors considered Cyrtospirifer syringothyriformis and $C$. verneuili as the "oldest and nominal elements" of the group.

Schemm-Gregory (2011, pp. 9, 11) declared $C$. syringothyriformis a "middle-late Givetian" species ranging "into the Frasnian", where it "became widespread in the Early Frasnian in Eurasia and by the Middle Frasnian in western North America".

To sum up, syringothyriformis, an abundant middle Frasnian variety of verneuili in Boulonnais, the type area of the species and the variety, was considered an abundant species in the upper Frasnian of the Dinant Basin, where it is also present in the rest of the Frasnian. It later spread as a full-fledged species over the middle and upper parts of the Frasnian of various regions of the world to end up with a range extending to the middle-upper Givetian, and a worldwide distribution in the Frasnian.

Many of the internal and external characters mentioned by Paeckelmann (1942) and Brice (1988) in their descriptions of syringothyriformis are to be found in other varieties of verneuili, as well as in other cyrtospiriferid species. This is particularly the case for the occasional presence of slight asymmetry of the shell, and ventral flanks near the cardinal extremities being slightly concave to flat.

Descriptions of syringothyriformis by Paeckelmann and Brice include slight discrepancies in evaluation of some characters like shape of the sulcus, fold and tongue. It is more difficult to explain that position of the dental plates in relation to the bounding costae of the sulcus was considered as coincident by Paeckelmann (1942, p. 124), clearly extrasinal by Brice (1988, p. 368), and intrasinal by Schemm-Gregory (2011, table 1, p. 6).

In order to best characterize syringothyriformis, such character as the micro-spinose ornament resulting in radial micro-striae simulated by the alignment of the spine bases observed by Brice (1988) must be added to the conjunction of the wide alate outline with the high ventral horizontal area originally advocated by Paeckelmann (1942). (Remark: high ventral area oscillates between a catacline and orthocline, exceptionally procline, position.)

Thus defined, syringothyriformis, no matter if it is considered a species or a variety of verneuili, is of early mid-Frasnian age and only present in the Ferques area of Boulonnais; its presence in the Aachen region needs confirmation.

\section{Discussion}

\subsection{The success story of disjunctus}

The lack of anchor did not prevent the species - at least, forms identified as such - to spread from England across the five continents with a marked success in the Dinant Basin (Belgium and France), Boulonnais, the Central Devonian Field (central Russian Platform), New York State, and South China.

All imaginable adjectives and substantives in English, French, German, Russian, etc. were bracketed to the English species: aff., cf., ex gr., authentic, beds, characteristic, congeneric, cycle, diagnostic epoch, fauna (faunal complex), forms (ecological form, intermediate form, special form, transitional form, typical form, "Stammform"), genes, group, mutants (mutant form, mutational form, characteristic mutant), polymorphic, proper, pulverisation, race (local race), sensu lato, sensu stricto, subspecies, transitional, true, type (typical, typical examples, widely disseminated form, type form, "feststehender Typus"), ubiquitous, variability, variation, varieties (morphological variety, special variety, individual variety), variant phase, zone (faunal zone, local zone, biozone, named for the species or a group of species containing it), guide fossil, index fossil, limestone(s).

Some sixty species and varieties at one time or another have been considered synonyms of disjuncta, among which four species also proposed by Sowerby, J. de C. in Sedgwick \& Murchison (1840), i.e. calcarata, extensa, gigantea, and 
inornata. The other synonyms include: Spirifer distans sensu Phillips, 1841 from the Devonian (probably Givetian) of South Devon (non S. distans sensu Sowerby, J. de C., 1825 from the Viséan of Ireland, non $S$. distans sensu Gosselet, 1860 from the Strunian of the southern border of the Dinant Basin); 'S. Gortanii' Pellizzari, 1913, introduced as 'S. disjunctus var. Gortanii', Upper Devonian (probably upper Frasnian), bought from a Chinese pharmacy in Shaanxi Province, China; S. yunnanensis Mansuy, 1912 from eastern Yunnan, introduced as ' $S$. Verneuili var. yunnanensis'; S. whitneyi Hall, 1858 from the upper Frasnian of northeastern Iowa; ' $S$. Murchisonianus' de Verneuil in Murchison et al., 1845 from the lower Frasnian of the western flank of Central Urals; S. aquilinus Romanovskiy, 1878 from the lower Famennian of eastern Kazakhstan; 'S. Brodi' Wenjukoff, 1886 from the Central Devonian Field (central Russian Platform); S. sulcifer Hall \& Clarke, 1893 from southwestern New York, introduced as $S$. disjunctus var. sulcifer.

As a consequence, the synonymy lists of disjunctus including verneuili, and, progressively, with time passing, one or more of the sixty species, subspecies and varieties mentioned above, are deprived of any consistency and value. Davidson's $(1864$, pp. 23,24$)$ list is a good example. This is also the case for the synonymy lists of verneuili that contain disjunctus, and usually represent just an account of citations, such as the one by Vandercammen (1959, pp.114-117) that incorporates previous mentions of the species, and its subspecies, varieties and mutations.

\subsection{The legendary equation disjunctus $=$ verneuili}

There is no indication in the literature on who was the first to clearly state that disjunctus is equal to verneuili, and how such a conclusion was reached. In the absence of any tangible explanation, various possibilities have to be explored in the way historians are often compelled to do. The author sees as a reasonable guess the assumption that the equation originated by means of exchanges of views and conversations held in the field or elsewhere by leading geologists. Murchison and de Verneuil visited, sometimes together, various Devonian sections in Devon, Cornwall and Boulonnais. They had in their hands specimens that were named the same year disjunctus by Sowerby, J. de C. in Sedgwick \& Murchison (1840) in Devon and Cornwall, and verneuili by Murchison (1840b) in Boulonnais. Lonsdale (1840, p. 285) reports that "Murchison procured a collection of specimens in the Museum of Boulogne", among which he identified two species as Spirifer, spec. nov. These identifications were included in the list of fossils from the Boulonnais by Murchison (1840a, pp. 240-241), who, subsequently, named one of them (probably "Spirifer, spec. nov. à côtes dichotomes") verneuili. Was it not tempting to conclude from the existence of some external, and even internal, similarities between the two species considered then to be of the same age, that they were synonyms? This problem was not of major importance when the Devonian System was in the making in England, and the recognition of its counterparts and subdivisions in continental Europe was occupying the minds of English and French geologists.

Of course, Murchison alone could have been the promoter of the equation disjunctus $=$ verneuili , and have benefited from his undisputed authority for having it accepted without any discussion by his colleagues and friends.

That the general consensus, prevailing around the middle of the nineteenth century, maintained itself without any attempt of demonstrating the affinities between disjunctus and verneuili, escapes any logical reasoning. Differences between species that are declared identical obviously do not need to be investigated, even if some related to size, outline, and costation were evident on the material available in 1840 .

De Verneuil in Murchison et al. (1845, p. 158) was the only one to express some reservation in writing that he "provisionally maintained the separation of the two species, without denying ("méconnaître"), however, their close affinity".

Reed (1943, p. 104) was the only one to express clear reservation when he wrote that it seemed to him that "the common British
Upper Devonian shell which Sowerby named Spirifer disjunctus is not a synonym of the typical $S$. verneuili. ... The view as to the specific individuality of $S$. disjunctus and $S$. verneuilii has been widely disputed, and in the literature of the subject they are usually considered to be inseparable, though chiefly on the assumption that $S$. verneuili is a very variable form".

As far as Nalivkin is concerned, he accepted the equivalence of the two species, but, although he used almost exclusively the terms "disjunctus beds" or "disjunctus fauna" in his publications, he was well inspired in choosing verneuili, and not disjunctus, as the type species of the genus Cyrtospirifer Nalivkin in Frederiks (1924).

\subsection{Disjunctus is not verneuili}

The opinion that disjunctus is a variety of verneuili, and vice versa is commonly found in the literature.

The confusion of disjunctus with verneuili should have come to an end when Gatinaud (1949, p. 487) designated Cyrtospirifer disjunctus as the type species of the genus Eurytatospirifer Gatinaud, 1949. Alas! The legend survived and was echoed in two recent authoritative compendia by Johnson (in Carter et al., 1994, p. 335; Johnson, 2006, p. 1726), who erroneously considered the genus Eurytatospirifer, and other genera, synonyms of the genus Cyrtospirifer, making a catch-all-name out of it, and endorsing indirectly Davidson's (1864, p. 24) statement that disjunctus was a "very important Middle and Upper Devonian species".

As far as the problems dealt with in the present paper are concerned, it is difficult to understand that obvious consequences of making out of the genus Eurytatospirifer a junior synonym of the genus Cyrtospirifer have not been imagined. On account of the eventual identity of the type species of the two genera, and if priority over verneuili is given to disjunctus, this species should become the type species of the genus Cyrtospirifer!

\section{Conclusions}

It is vain to search through the literature the name of the scientist who first stated that disjunctus and verneuili represent one and the same species, and why. Anyhow, such an identity was unanimously accepted around the middle of the nineteenth century by the leading English, French and German palaeontologists, and the concept that should never have been put forward is still alive.

The type series of disjunctus and verneuili are each composed of three different specimens, and there is not much similarity between the six specimens. Pellizzari (1913, pp. 34-35) clearly depicted a situation that was obvious at the very outset, in writing: "figures of Sowerby are unfortunate ("infelici") and his description is defective ... figures and diagnosis of Sowerby are insufficient for characterizing the species ['Spirifera disjuncta'], and are not even sufficient for characterizing one of its varieties". Two of the types of verneuili have been considered juveniles by Murchison (1840b, p. 252), and the third one exceptional, rare, and gerontic by Vandercammen (1959, fig. 89, p. 117) and Brice (1988, p. 365).

Lectotypes have been designated in the present paper, the one of verneuili being only a substitution for the "holotype" that was proposed without taking into consideration the Article 73.1 of the International Code of Zoological Nomenclature (see ICZN 1999, pp. 79-80). This opens the door for a proper definition of disjunctus and verneuili.

These species are of different age in their type areas, as we already know for a long time: Strunian for the lectotype, and late Famennian for paratypes A and B of disjunctus, late midFrasnian for the lectotype and the paralectotypes of verneuili. For both species, however, given age in the world literature is Givetian to Early Carboniferous (chiefly Frasnian and Famennian).

It is obvious that the problem of the priority of disjunctus over verneuili or of verneuili over disjunctus that has often been evoked, sometimes at length, in the literature, is irrelevant, since the two species differ, in size and shape of the shell, and in costation. 
Erroneous equation of disjunctus with verneuili has contributed to blear the definition of the genus Cyrtospirifer considered as globally distributed and an index fossil for the Upper Devonian with, as a consequence, a few valid genera being erroneously considered its synonyms at one time or another.

These conclusions should be the starting point of a comprehensive future re-description and comparison of the two species - based on the lectotypes selected and additional topotypical materials.

\section{Acknowledgements}

The author is indebted to Matt Riley (The Sedgwick Museum of Earth Sciences, University of Cambridge) and to Sarah L. Long (The Natural History Museum, London), who allowed him to go through the collections under their care during visits to these institutions. Collections of spiriferids from Barnstaple and Petherwin were generously sent on loan by Matt Riley, and by Zoe Hughes (The Natural History Museum, London) with permission to take photographs of the specimens illustrated in the present paper. The paper could not have been written without this invaluable assistance. Fernando Alvarez (Universidad de Oviedo, Spain) and Ulrich Jansen (Senckenberg Forschungsinstitut und Naturmuseum Frankfurt, Germany) are thanked for their constructive reviews, as well as Maria Hecker-Sartenaer (Brussels) for the meticulous follow-up of the latest version, which all improved the manuscript.

\section{References}

Brice, D., 1982. Comments on the distribution of some selected brachiopods for the latest Givetian and early Frasnian periods in the Boulonnais (Ferques) and the Massif Armoricain (rade de Brest). In Sartenaer, P. (ed.), Papers on the Frasnian/Givetian boundary. Geological Survey of Belgium, Brussels, 5-16.

Brice, D., 1986. Place et morphologie des Brachiopodes dans les assemblages benthiques du Givétien et du Frasnien de Ferques (Boulonnais, Nord de la France): essai d'interprétation paléoécologique. In Racheboeuf, P.R. \& Emig, C. (eds), Les Brachiopodes fossiles et actuels. Actes du $1^{\text {er }}$ Congrès International sur les Brachiopodes, Brest, 9-13 septembre 1985. Biostratigraphie du Paléozoïque, 4, 197-208.

Brice, D., 1988. Brachiopodes du Dévonien de Ferques (Boulonnais - France). In Brice, D. (ed.), Le Dévonien de Ferques. BasBoulonnais (N. France). Paléontologie - Sédimentologie Stratigraphie - Tectonique. Biostratigraphie du Paléozoïque, 7, 323-395.

Brice, D., Bultynck, P., Deunff, J., Loboziak, S. \& Streel, M., 1979. Données biostratigraphiques nouvelles sur le Givétien et le Frasnien de Ferques (Boulonnais, France). Annales de la Société géologique du Nord, 98/4 (1978), 325-344.

Carter, J.L., Johnson, J.G., Gourvennec, R. \& Hou, H.-F., 1994. A revised classification of the spiriferid brachiopods. Annals of Carnegie Museum, 63/4, 327-374.

Cocks, L.R.M., 1989. Lower and Upper Devonian brachiopods from the Budleigh Salterton Pebble Bed, Devon. Bulletin of the Museum (Natural History), Geology Series, 45/1, 21-37.

Davidson, T., 1864-1865. A Monograph of the British fossil Brachiopoda, 3: Devonian and Silurian species with observations on the classification of the Silurian rocks by Sir Roderick Impey Murchison, 6: The Devonian Brachiopoda. Palaeontographical Society, London, $131 \mathrm{p}$.

Devos, I., 1962. Contribution à l'étude du Givétien et du Frasnien du Boulonnais. Unpublished D.E.S. thesis. Université de Lille, France, $81 \mathrm{p}$.

Frederiks, G., 1924. On the Upper Carboniferous spiriferids of the Urals. Izvestiya Geologicheskogo Instituta, 38/3 (1919), 295-324.

Gatinaud, G., 1949. Contributions à l'étude des Brachiopodes Spiriferidae. Exposé d'une nouvelle méthode d'étude de la morphologie externe des Spiriferidae à sinus plissé. Bulletin du Museum national d'Histoire naturelle, 21 (1, 2, 3, 4), 153-159, 300-307, 408-413, 487-492.

Gosselet, J., 1860. Mémoire sur les terrains primaires de la Belgique, des environs d'Avesnes et du Boulonnais. Paris, L. Martinet, 164 p.

Gosselet, J., 1894. Étude sur les variations du Spirifer Verneuili. Mémoires de la Société géologique du Nord, 4/1, 1-61.

Grabau, A.W., 1931-1933. Devonian Brachiopoda of China, 1: Devonian Brachiopoda from Yunnan and other districts in South China. Palaeontologica Sinica, 3/3, 1-545.
Hall, J., 1858. Report on the Geological Survey of the State of Iowa, embracing the results of investigations made during portions of the years 1855, 56 \& 57, 1 (Part 2: Palaeontology). Published by authority of the legislature of Iowa. Ch. Van Benthuisen, 473724.

Hall, J. \& Clarke, J.M., 1893-1894. Natural History of New York, Part VI, Palaeontology, vol. VIII: An introduction to the study of the genera of Palaeozoic Brachiopoda, Part II. Geological Survey of the State of New York, Albany, $394 \mathrm{p}$.

ICZN (International Commission on Zoological Nomenclature), 1999. International Code of Zoological Nomenclature, 4th ed. The International Trust for Zoological Nomenclature, London, xxix, $306 \mathrm{p}$.

Johnson, J.G., 2006. Cyrtospiriferoidea. In Kaesler, R.L. (ed.), Treatise on Invertebrate Paleontology, Part H, Brachiopoda (revised), vol. 5. Geological Society of America, Boulder, Colorado, and The University of Kansas, Lawrence, 1722-1732.

Joseph, J., Brice, D. \& Mouravieff, N., 1980. Données paléontologiques nouvelles sur le Frasnien des Pyrénées centrales et occidentales : implications paléogéographiques. Bulletin de la Société d'Histoire naturelle de Toulouse, 116/1-2, 16-41.

Lonsdale, W., 1840. On the age of the limestones of South Devon. Proceedings of the Geological Society of London, 3/69, 281-286.

Ma, X. \& Day, J., 2003. Revision of selected North American and Eurasian Late Devonian (Frasnian) species of Cyrtospirifer and Regelia (Brachiopoda). Journal of Paleontology, 77/2, 267-292.

Mansuy, H., 1912. Étude géologique du Yun-Nan oriental. IIe partie, Paléontologie. Mémoires du Service géologique d'Indochine, 2, 1-146.

Mistiaen, B., Brice, D., Loones, C. \& De Sousa, A., 2012. Un affleurement temporaire exposant le contact entre les Formations de Beaulieu et de Ferques (Frasnien, Boulonnais). Annales de la Société Géologique du Nord, 19, 39-47.

Murchison, R.I., 1840a. Sur les roches dévoniennes, type particulier de l'old red sandstone des géologues anglais, qui se trouvent dans le Boulonnais et les pays limitrophes. Bulletin de la Société géologique de France, 11 (1839-1840), 229-250.

Murchison, R.I., 1840b. Description de quelques unes des coquilles fossiles les plus abondantes dans les couches devoniennes du BasBoulonnais. Bulletin de la Société géologique de France, 11 (18391840), 250-257.

Murchison, R.I., Verneuil, E. \& Keyserling, A. de, 1845. Géologie de la Russie d'Europe et des Montagnes de l'Oural, vol. 2, $3^{\mathrm{e}}$ partie, Paléontologie. John Murray, London, and Bertrand, Paris, $512 \mathrm{p}$.

Paeckelmann, W., 1942. Beiträge zur Kenntnis devonischer Spiriferen. Abhandlungen des Reichsamts für Bodenforschung, 197, 1-188.

Pellizzari, G., 1913. Fossili paleozoici antichi della Scensi (Cina). Rivista Italiana di Paleontologia, 19/2, 33-48.

Phillips, J., 1841. Figures and descriptions of the Palaeozoic fossils of Cornwall, Devon, and West Somerset. Geological Survey of Great Britain, Memoirs, 1, 1-231.

Reed, F.R.C., 1943. Notes on certain Upper Devonian brachiopods figured by Whidborne. Geological Magazine, 80 (2, 3, 4), 69-78, 95-106, 132-138.

Romanovskiy, G.D., 1878. Materialy dlya geologii Turkestanskogo kraya. Vypusk I. Geologicheskiy i paleontologicheskiy obzor severo-zapadnogo Tyan'-Shanya i yugo-vostochnoy chasti Turanskoy nizmennosti. Imperatorskaya Akademiya Nauk, St. Petersburg, 167 p. [In Russian].

Schemm-Gregory, M., 2011. A new species of Cyrtospirifer (Brachiopoda) from the Middle Devonian of the Western Sahara (Northwestern Africa). Rivista Italiana di Paleontologia e Stratigrafia, 117/1, 3-13.

Sedgwick, A. \& Murchison, R.I., 1840. On the Physical structure of Devonshire, and on the Subdivisions and Geological Relations of its older stratified Deposits, \& c. Transactions of the Geological Society of London, 5, 633-705.

Sokiran, E.V., 2013. Cyrtospirifer vjacheslavi - novy vid brakhiopod (Cyrtospiriferidae, Brachiopoda) iz srednefranskikh otlozheniy Vostochno-Evropeiskoy platformy. Paleontologicheskiy Zhurnal, 6, 24-28. [In Russian].

Sowerby, J. De Carle, 1825. The mineral conchology of Great Britain or coloured figures and descriptions of those remains of testaceous animals or shells, which have been preserved at various times and depths in the earth, vol. 5. Richard Taylor, London, 139-168.

Vandercammen, A., 1959. Essai d'étude statistique des Cyrtospirifer du Frasnien de la Belgique. Mémoires de l'Institut royal des Sciences naturelles de Belgique, 145, 1-175.

Wenjukoff, P.N., 1886. Die Fauna des devonischen Systems im nordwestlichen und centralen Russland. Geologisches Cabinet der Kaiserlichen Universität zu St-Petersburg, 308 p.

Manuscript received 04.12.2015, accepted in revised form 14.10.2017, available on line 20.12.2017. 


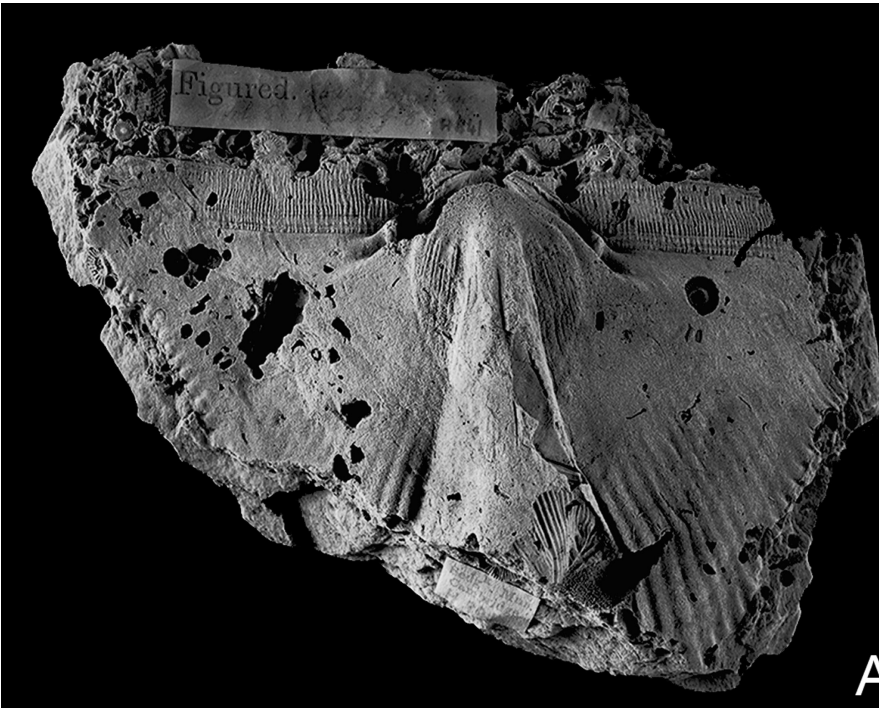

A
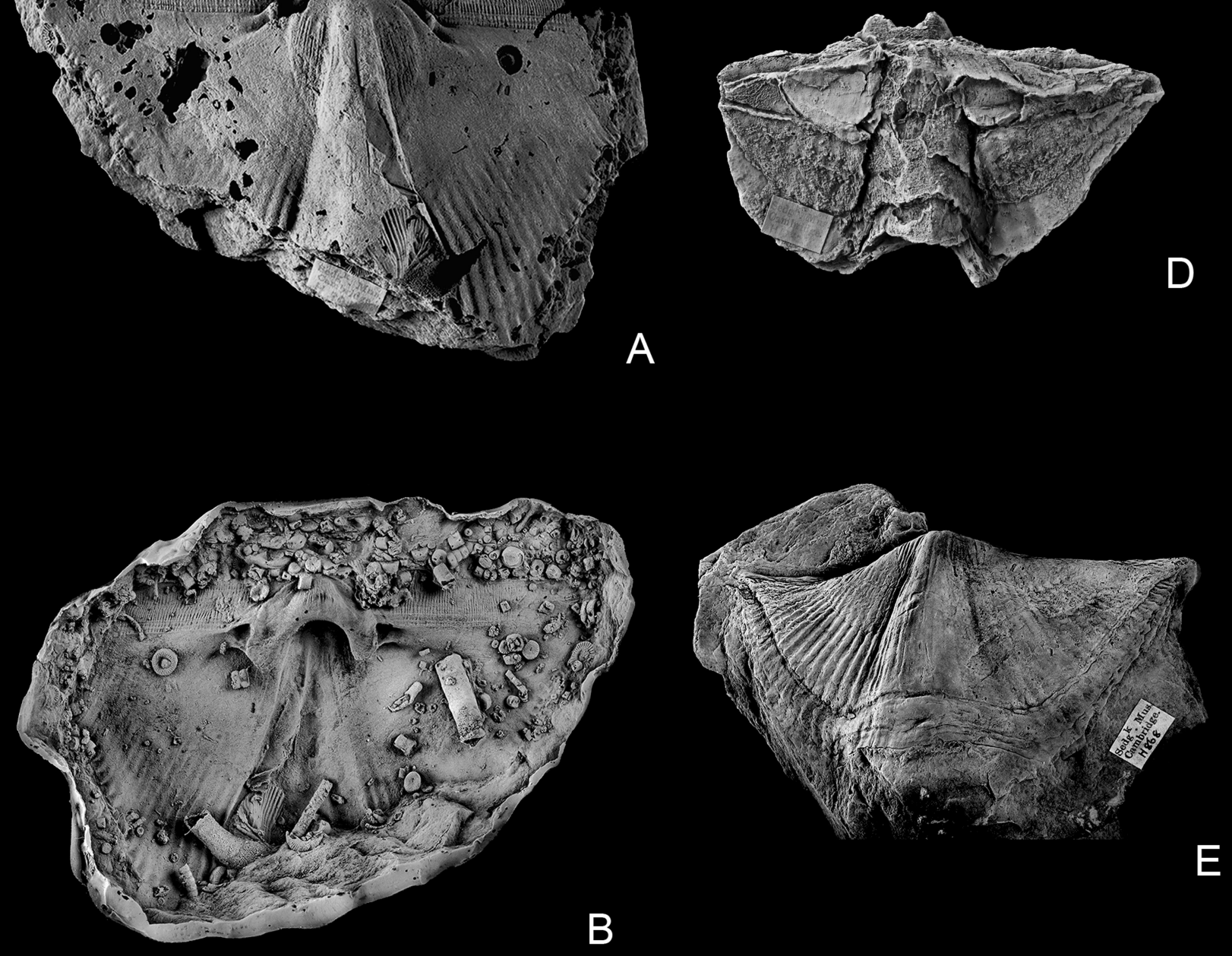

$\mathrm{B}$
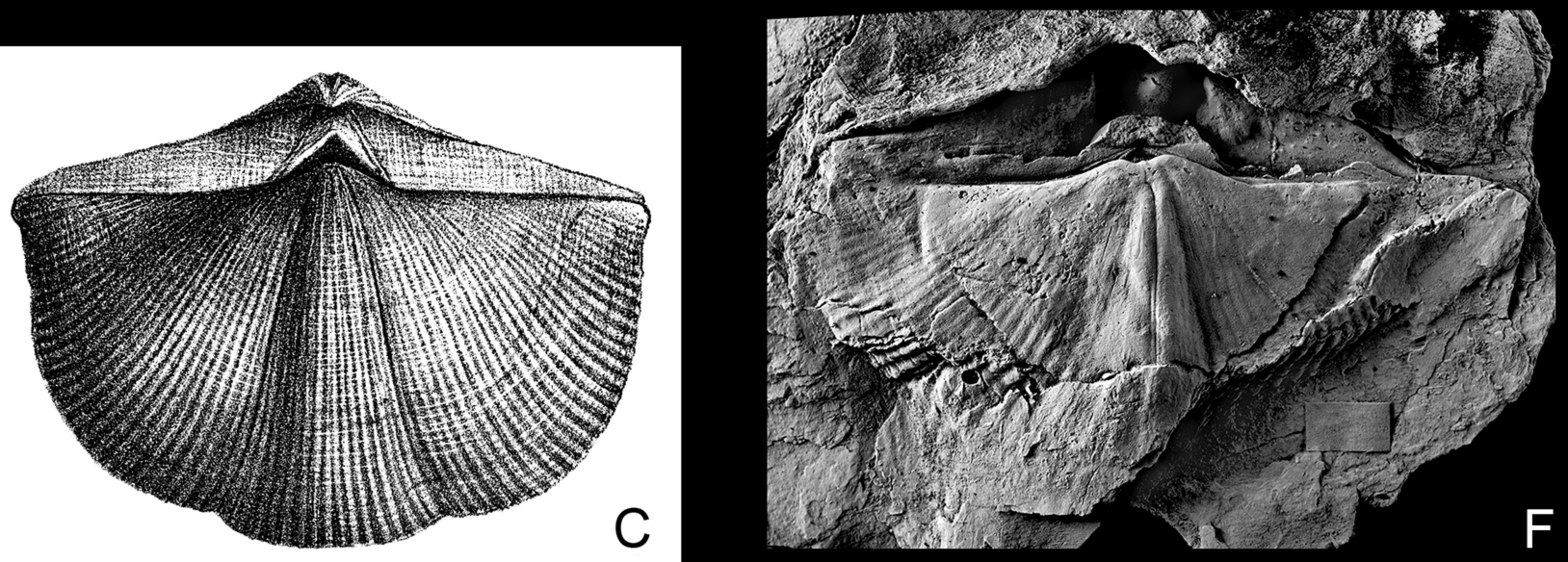

Plate 1. Spirifer disjunctus (Sowerby, J. de C. in Sedgwick \& Murchison, 1840). A-B: Lectotype of 'Spirifera disjuncta' Sowerby, J. de C. in Sedgwick \& Murchison, 1840, CAMSM H.841, large specimen; A: mould, almost complete dorsal valve and the interarea of the ventral valve = pl. LIII, fig. 8 of Sowerby, J. de C. in Sedgwick \& Murchison, 1840 (figured without the margin of the anterior border); B: internal cast of same specimen; Barnstaple, North Devon, Upper Devonian. C: Large specimen identified as 'Spirifera disjuncta' = 'Sp. Verneuili'; South Petherwin, North Cornwall, Upper Devonian (after Davidson, 1864, pl. V, fig. 3). D-F: Specimens of various sizes labelled Spirifer disjunctus = Verneuili; Barnstaple, North Devon, Upper Devonian; D: CAMSM H.1342, dorsal view of complete and crushed specimen of medium size; E: CAMSM H.868, dorsal valve of a specimen of medium size; F: CAMSM H.859, isolated dorsal valve and broken ventral interarea of a specimen of the size of the lectotype. All figures are natural size. 


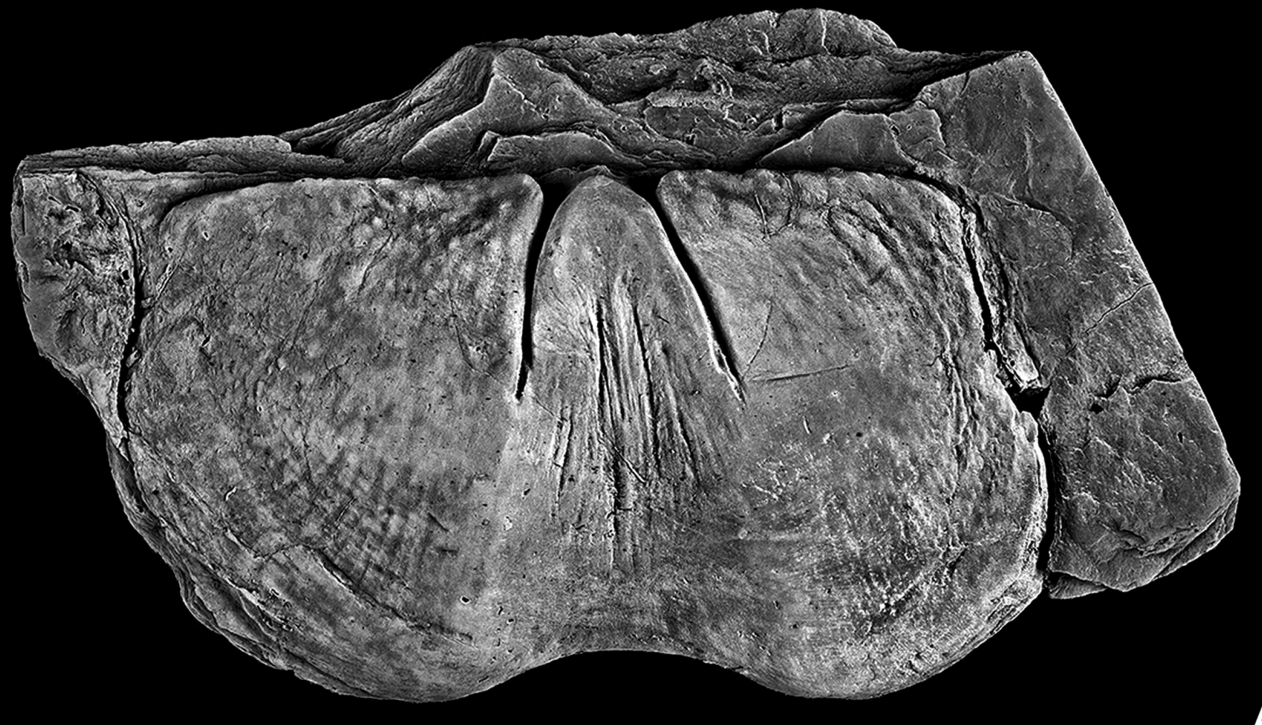

A

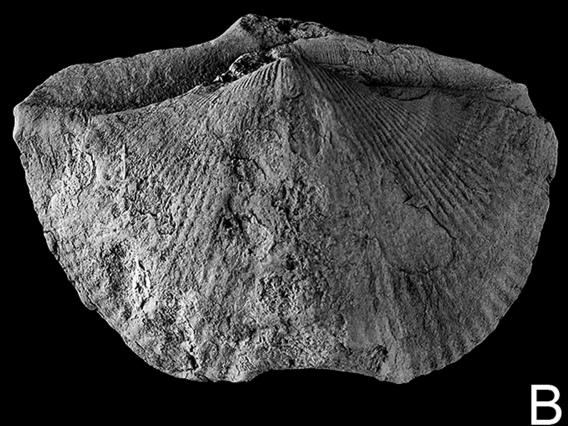

B

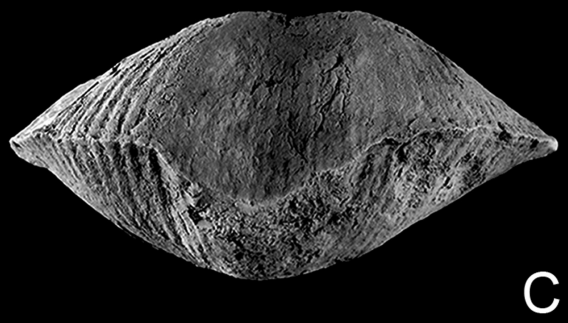

C

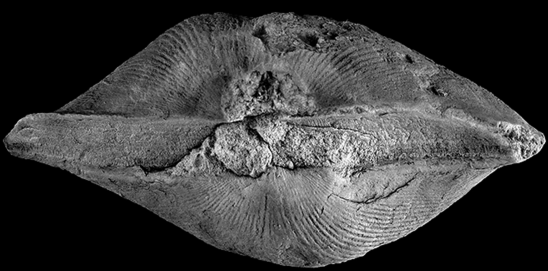

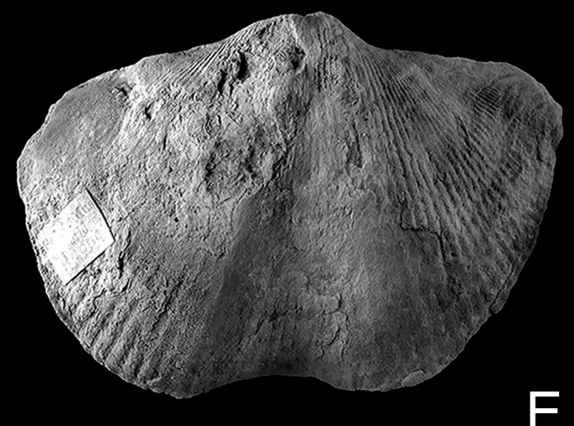

$E$

$\mathbf{F}$

$\mathrm{D}$
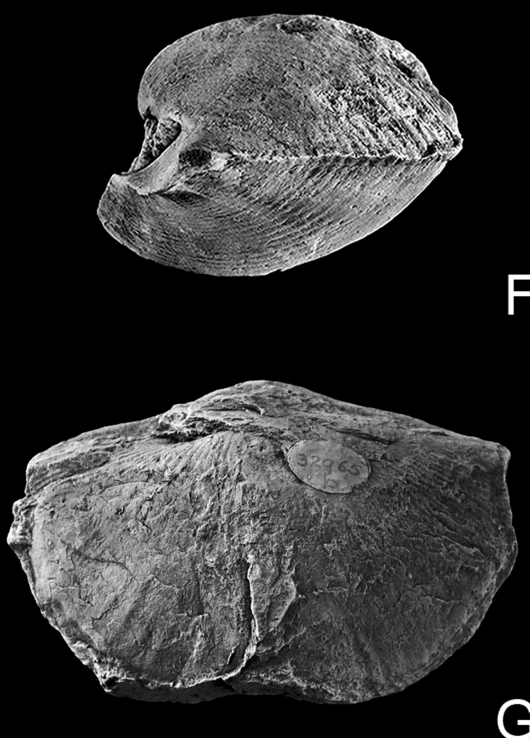

G

Plate 2. Spirifer disjunctus (Sowerby, J. de C. in Sedgwick \& Murchison, 1840). A-F: Paralectotypes of 'Spirifera disjuncta' Sowerby, J. de C. in Sedgwick \& Murchison, 1840; Petherwin, North Cornwall, Upper Devonian; A: paralectotype A, CAMSM H.4008, mould, very large, flattened, distorted and poorly preserved ventral valve $=$ pl. LIV, fig. 12 of Sowerby, J. de C. in Sedgwick \& Murchison, 1840; B-F: paralectotype B, CAMSM H.4009, complete specimen, dorsal (B) (= pl. LIV, fig. 13 of Sowerby, J. de C. in Sedgwick \& Murchison, 1840), anterior, with ventral valve on top (C), posterior (D), ventral (E), and lateral (F) views. G: BMNH 32965b, mould of a complete specimen labelled Spirifer verneuili, showing an outline similar to the one of paralectotype B, dorsal view; South Petherwin, North Cornwall, Upper Devonian. All figures are natural size. 